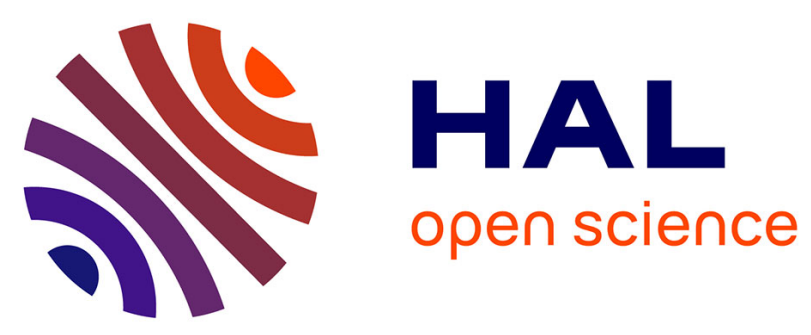

\title{
Research agenda on biodiversity and ecosystem functions and services in European cities
}

Pedro Pinho, Joan Casanelles-Abella, Ana Catarina Luz, Anna Maria

Kubicka, Cristina Branquinho, Lauri Laanisto, Lena Neuenkamp, Marta Alós

Ortí, Martin K Obrist, Nicolas Deguines, et al.

\section{To cite this version:}

Pedro Pinho, Joan Casanelles-Abella, Ana Catarina Luz, Anna Maria Kubicka, Cristina Branquinho, et al.. Research agenda on biodiversity and ecosystem functions and services in European cities. Basic and Applied Ecology, 2021, 53, pp.124-133. 10.1016/j.baae.2021.02.014 . hal-03322704

\section{HAL Id: hal-03322704 \\ https://hal-univ-poitiers.archives-ouvertes.fr/hal-03322704}

Submitted on 19 Aug 2021

HAL is a multi-disciplinary open access archive for the deposit and dissemination of scientific research documents, whether they are published or not. The documents may come from teaching and research institutions in France or abroad, or from public or private research centers.
L'archive ouverte pluridisciplinaire HAL, est destinée au dépôt et à la diffusion de documents scientifiques de niveau recherche, publiés ou non, émanant des établissements d'enseignement et de recherche français ou étrangers, des laboratoires publics ou privés. 


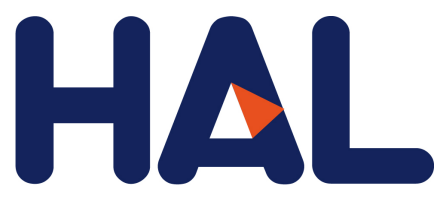

archives-ouvertes

\section{Research agenda on biodiversity and ecosystem functions and services in European cities}

Pedro Pinho, Joan Casanelles-Abella, Ana Catarina Luz, Anna Maria Kubicka, Cristina Branquinho, Lauri Laanisto, Lena Neuenkamp, Marta Alós Ortí, Martin Obrist, Nicolas Deguines, et al.

\section{To cite this version:}

Pedro Pinho, Joan Casanelles-Abella, Ana Catarina Luz, Anna Maria Kubicka, Cristina Branquinho, et al.. Research agenda on biodiversity and ecosystem functions and services in European cities. Basic and Applied Ecology, Elsevier, 2021, 53, pp.124-133. 10.1016/j.baae.2021.02.014 • hal-03322704

\section{HAL Id: hal-03322704 \\ https://hal-univ-poitiers.archives-ouvertes.fr/hal-03322704}

Submitted on 19 Aug 2021

HAL is a multi-disciplinary open access archive for the deposit and dissemination of scientific research documents, whether they are published or not. The documents may come from teaching and research institutions in France or abroad, or from public or private research centers.
L'archive ouverte pluridisciplinaire HAL, est destinée au dépôt et à la diffusion de documents scientifiques de niveau recherche, publiés ou non, émanant des établissements d'enseignement et de recherche français ou étrangers, des laboratoires publics ou privés. 


\title{
Research agenda on biodiversity and ecosystem functions and services in European cities
}

\author{
Pedro Pinho ${ }^{\mathrm{a}, *}$, Joan Casanelles-Abella ${ }^{\mathrm{b}, \mathrm{c}}$, Ana Catarina Luz ${ }^{\mathrm{d}}$, Anna Maria Kubicka ${ }^{\mathrm{e}}$, Cristina Branquinho ${ }^{\mathrm{a}}$, \\ Lauri Laanisto $^{\mathrm{f}}$, Lena Neuenkamp ${ }^{\mathrm{g}}$, Marta Alós Ortíf ${ }^{\mathrm{f}}$, Martin K. Obrist ${ }^{\mathrm{b}}$, Nicolas Deguines ${ }^{\mathrm{h}, \mathrm{k}}$, \\ Piotr Tryjanowski ${ }^{\mathrm{e}}$, Roeland Samson ${ }^{\mathrm{i}}$, Ülo Niinemets ${ }^{\mathrm{f}, \mathrm{j}}$, Marco Moretti ${ }^{\mathrm{b}}$
}

${ }^{a}$ Centre for Ecology, Evolution and Environmental Changes, Faculdade de Ciências, Universidade de Lisboa, Lisbon, Portugal

${ }^{\mathrm{b}}$ Biodiversity and Conservation Biology, Swiss Federal Institute for Forest, Snow and Landscape Research WSL, Birmensdorf, Switzerland

${ }^{\mathrm{c}}$ Landscape Ecology, Institute of Terrestrial Ecosystems, ETH Zürich, Zürich, Switzerland

${ }^{\mathrm{d}}$ ISEG - Lisbon School of Economics \& Management, Universidade de Lisboa, Portugal

e Institute of Zoology, Poznań University of Life Sciences, Poznan, Poland

${ }^{\mathrm{f}}$ Institute of Agricultural and Environmental Sciences, Estonian University of Life Sciences, Tartu, Estonia

${ }^{\mathrm{g}}$ Institute of Plant Science, University of Bern, Bern, Switzerland

${ }^{\mathrm{h}}$ Université Paris-Saclay, CNRS, AgroParisTech, Ecologie Systématique Evolution, Orsay, France

i Laboratory of Environmental and Urban Ecology, University of Antwerp, Antwerp, Belgium

${ }^{\mathrm{j}}$ Estonian Academy of Sciences, Tallinn, Estonia

${ }^{\mathrm{k}}$ Laboratoire Ecologie et Biologie des Interactions, Equipe Ecologie Evolution Symbiose, Université de Poitiers, UMR CNRS 7267, France

\section{A R T I CLE I N F O}

\section{Article history:}

Received 3 June 2020

Accepted 24 February 2021

Available online $\mathrm{xxx}$

\section{Keywords}

Citizen science

Habitat mapping

Multiple environmental gradients

Neglected habitats and niches

Species traits

Urban ecology

\begin{abstract}
A B S T R A C T
Cities are challenging environments for human life, because of multiple environmental issues driven by urbanization. These can sometimes be mitigated through ecosystem services provided by different functions supported by biodiversity. However, biodiversity in cities is affected by numerous factors, namely habitat loss, degradation, and fragmentation, as well as pollution, altered climate, and new biotic challenges. To better understand the link between biodiversity and ecosystem functions and services, we need to improve our mechanistic knowledge of these relationships. Trait-based ecology is a promising approach for unravelling the causes and consequences of biodiversity filtering on ecosystem processes and underlying services, but large gaps remain unexplored.Here, we present a series of research directions that are aimed at extending the current knowledge of the relationship between trait-based biodiversity and ecosystem functions and services in cities. These directions are based on: (1) improving urban habitat mapping; (2) considering often neglected urban habitats and ecological niches; (3) integrating multiple urban gradients; (4) using trait-based approaches to improve our mechanistic understanding of the relationships between biodiversity and ecosystem functions and services; and (5) extending the involvement of citizens.Pursuing these research directions may support the sustainable management of urban ecosystems and the long-term provision of ecosystem services, ultimately enhancing the well-being of urban populations.
\end{abstract}

\section{Introduction}

Humans and their activities have been transforming the Earth and its ecosystems in multiple ways, including alterations of the landscape, disturbance regimes, species distributions and interactions (Boivin et al., 2016). Urbanization is one such global trend within the Anthropocene, impacting people, biodiversity and consequently ecosystem functions (EF) and services (ES).

\footnotetext{
* Corresponding author.

E-mail address: ppinho@fc.ul.pt (P. Pinho)
}

Cities are socio-ecological systems mostly dominated by the grey infrastructure (built-up area, including buildings and roads) and the green and blue infrastructure, which include all natural, semi-natural and artificial (i.e. entirely human-made) habitats within a city, such as parks, rivers and green-roofs. Despite their socio-economic benefits, urban areas are a challenging environment for city-dwellers (Engemann et al., 2019). For instance, cities typically have higher temperatures and more air pollution than rural areas (Munzi et al., 2014). To mitigate these urban problems, cities can rely on a mixture of technological and nature-based solutions to provide key services, including climate and water regulation, noise reduction, air filtration and recreational and aesthetic value (Capotorti et al., 2019; Diaz et al., 2018; 
IPBES, 2019). Recently, the added value of green spaces to ameliorate the multiple negative impacts of pandemic situations (such as the CoVid-19) on human well-being is being heighted by a sharp increase in visitation to such green areas (Grima et al., 2020). Nature-based solutions are intended to benefit both people and nature, with the added advantage of promoting biodiversity and fostering cities as socio-ecologically resilient systems (Elmqvist, Andersson \& Frantzeskaki, 2019).

Biodiversity faces multiple challenges in cities, including habitat fragmentation and high spatio-temporal disturbances when compared to non-urban areas. Changes in biodiversity and species composition due to these stressors often cascade down to shifts in EF and ES provisioning, including the potential loss of key ES (e.g., (Tresch et al., 2019b)). These stressors can also impact species composition with knock-on effects on ES provisioning due to species-specific responses depending on species traits, for example causing a decline in pollination service (measured by flower visitation) through favouring Hymenoptera in cities compared to Diptera and Lepidoptera (Theodorou et al. 2020). The need for ES provisioning differs across cities, depending on cultural, political, socio-economical, and historical aspects, as well as topographic, climatic, and geological conditions (Ossola, Locke, Lin \& Minor, 2019). Nonetheless, biodiversity is universally shaped by a set of factors that filter the regional species pool and select for adapted species that might result in functionally similar species assemblages (Fournier, Frey \& Moretti, 2020). In this regard, research approaches based on traits, i.e. phenotypic features of organisms that affect their fitness (Violle et al. 2007), have been proposed. Still, the relative contribution of different components of biodiversity and the mechanisms behind the provision of ES remains understudied (Schwarz et al., 2017). Moreover, studies about urban ecology, as in other fields of ecology (Meyer, Weigelt \& Kreft, 2016), have some major spatial and taxonomic biases. Many studies can only cover a subset of the existing ecological components (e.g. through targeting specific habitats or times of the day) and taxonomic groups, ultimately limiting the knowledge on the relationship between biodiversity and EF.

Since cities are socio-ecological systems driven by human perceptions and needs, citizen science programs can provide important contributions to biodiversity data and promote awareness among city residents. Citizen science programs could ultimately help fill gaps in the knowledge of species' distributions and their relationships to ES in cities (Serret, Deguines, Jang, Lois \& Julliard, 2019). To overcome these knowledge gaps a comprehensive overview on trait-based biodiversity $\mathrm{EF}$ and ES research in cities is needed as a solid basis for future research agendas including academic and citizen sciences approaches. Building on extensive literature research focussed on the relationships between biodiversity, EF and ES provision, and on the questions raised during the development of the European research project BioVeins (Connectivity of green and blue infrastructures: living veins for biodiverse and healthy cities, BiodivERsA3201510), we identified multiple knowledge gaps for biodiversity, EF and ES research in cities. Acknowledging that these gaps could be tackled using an approach based on the quantification of EF and ES and their relationships with biodiversity, and with the ultimate objective of promoting resilient cities, we present a series of research directions that point towards: (1) improving urban habitat mapping; (2) considering neglected urban habitats and ecological niches; (3) integrating multiple urban environmental gradients; (4) using trait-based approaches to improve our mechanistic understanding of biodiversity and its relationship with EF and ES; and (5) extending the involvement of citizens in biodiversity, EF and ES research. A conceptual scheme of the research agenda is presented in Fig. 1.

Research agenda to assess biodiversity, EF and ES in cities

\section{Improving urban habitat mapping}

Urban biodiversity research needs detailed knowledge of the habitat types and their spatial distribution in cities. Habitat composition in the Natura 2000 network of protected areas is being characterized through a coordinated effort at the European level (EC, 2020), but this work remains limited to case studies and does not provide extensive mapping

\section{Research agenda on biodiversity and ecosystem functions and services in European cities}

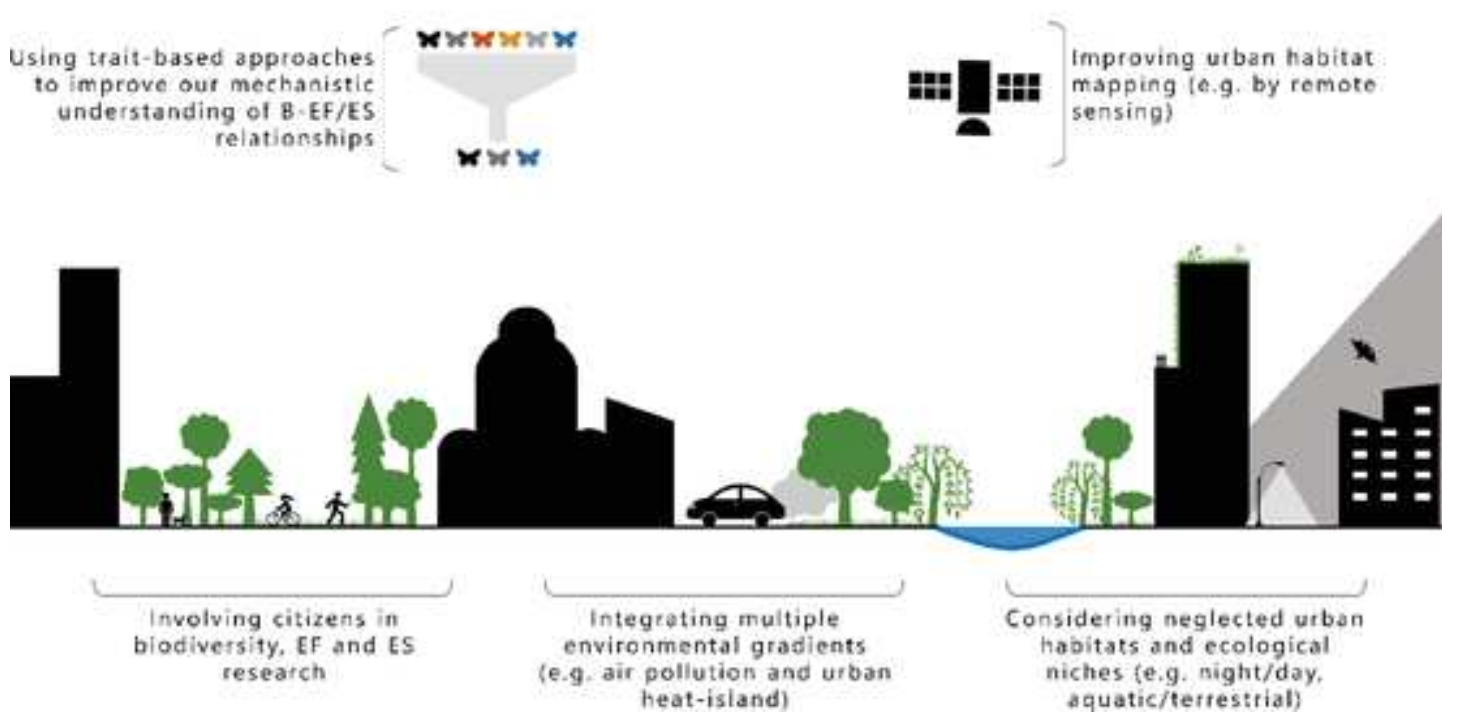

Fig. 1. Conceptual research agenda to improve our understanding of relationships between biodiversity and ecosystem functions and services (B-EF/ES) in cities. The five topics highlighted by text sections are discussed in detail in the main text. 
of urban areas. Some cities, such as Zurich or Paris, map their habitats at a very fine spatial resolution, and city-scale studies can make use of these resources. However, thematic and temporal resolutions are not compatible, and standard habitat mapping is currently not available at the European level (Kabisch, Strohbach, Haase \& Kronenberg, 2016). Although the European Urban Atlas (EEA., European Environmental Agency, 2012) uses a consistent set of rules for mapping, its habitat definition is limited to only three classes: 'Green Urban Areas', 'Forest', and 'Herbaceous Vegetation Association', and it omits key attributes, such as vegetation structure and management, which are critical for linking them to biodiversity (Pinho et al., 2016) and ES provisioning (Mexia et al., 2018). Moreover, small habitat patches, such as green roofs and walls, flower beds and domestic gardens, as well as linear elements, such as green belts and ecotones, are often omitted even though they are novel urban habitats with critical features for biodiversity and ES provision (Hand et al., 2017).

Remote sensing data can be an important source for mapping urban land use. Unlike land-cover maps, remote sensing data is continuous over space, can be continuously updated, and has been used in urban areas to assess e.g. carbon stocks, urban heat island hotspots (Dobbs, Hernandez-Moreno, Reyes-Paecke \& Miranda, 2018) and patterns of urban biodiversity (Pellissier, Mimet, Fontaine, Svenning \& Couvet, 2017). An added value of remote sensing is that it enables rapid collection of data that can be used for monitoring and as part of an early warning system, i.e. signalling areas that are currently unchanged but that are likely to undergo changes in the future, such as drought-induced tree mortality, based on time-series analysis (Yanlan et al. 2019). This area of research remains unexplored regarding biodiversity changes.

To avoid the pitfalls of using linear city-centre to peri-urban gradients to characterize polycentric cities (Ramalho \& Hobbs, 2012), future studies should consider the characteristics of each habitat patch and its surroundings, irrespective of its geographical position and distance from the city centre. This can be done, for example, by stratifying sampling to the environmental factor of interest or to a proxy of environmental factors (e.g. dense urban landcover as a proxy for air pollution) (Pinho et al., 2016). Future work using spatially complete analyses (Pinho et al., 2008) could provide further insights into species-specific mechanisms (such as dispersion) or the spatial structure of underlying socio-ecological factors (such as management intensity, urban heat-island effect and equity in the distribution of ES).

\section{Research directions - urban habitat mapping:}

1. Create ecologically meaningful habitat-based maps of cities, including the full range of land uses, management strategies and habitat sizes.

2. Use remote sensing data series to create a spatially complete and temporally replicated sampling design, enabling better characterization of urban habitats and long-term processes.

\section{Considering neglected urban habitats and ecological niches}

Typically, urban areas contain three main land cover types: artificial built-up area, e.g. houses and roads (grey infrastructure), terrestrial and aquatic habitats (green and blue infrastructures, respectively). Although these land covers are intermingled in cities in space and time, they are often studied separately regarding: (1) their identity (green, blue, grey); (2) their vertical distribution (above vs. below the surface), (3) the time of day when the investigation occurs (day vs. night) and (4) typology (e.g. green roof vs. meadow). However, urban habitats are perceived and used by most animals as a continuum, since they often depend on more than one habitat to complete their life cycle or to perform important activities, such as reproduction, nesting, and foraging (Colding, 2007). Moreover, it is important not to minimize the importance of the below-ground habitat to many organisms, including bacteria, arthropods, fungi, and snails. Belowground biodiversity is tightly connected with the aboveground compartment through processes such as leaf litter decomposition, nutrient exchange, and soil formation. Participating in shaping primary productivity, the roles of belowground biodiversity thus cascades into the next trophic levels, ultimately determining other ES such as pest control, pollination, and food production (Tresch et al., 2019a). Such nutrient and energy transfers across neighbouring habitats are expected to be intense but remain largely unexplored.

Day and night provide two contrasting habitat spaces and ecological niches for nocturnal and diurnal organisms. Nocturnal habitats are key for species such as bats, ground-dwelling arthropods, moths and a myriad of other insects that carry out a range of under-studied ES in cities, such as pollination of night-flowering plants (Knop et al., 2017) and pest control. While other animals such as birds share the same space during the day, only by looking at both, nocturnal and diurnal organisms, we can have a complete perspective on the local food webs (Villarroya-Villalba et al., 2021).

To balance the impossibility of investigating all ecological niches and habitats during the whole life cycle of organisms, we can focus on traits related to daily and annual activity time, voltinism (number of generations an organism completes within a year), and ontogeny (the developmental history of an organism during its lifetime; see Moretti et al. (Moretti, Dias \& De Bello, 2017) for terrestrial invertebrates, Pérez-Harguindeguy et al. (2013) for plants, and Dawson et al. (Dawson, Boddy \& Halbwachs, 2019) for fungi). Moreover, by investigating trait variation at the individual rather than species level, one could consider phenotypic plasticity and possible adaptations to the particular environmental conditions in cities, thereby shedding light on important eco-evolutionary mechanisms that need to be explored further at the genetic level (Uchida et al., 2021).

\section{Research directions - neglected habitats and niches:}

1. Use trait-based approaches to understand species' responses to unexplored niches and to compare responses across taxa, cities and regions.

2. Investigate intraspecific trait variability to quantify phenotypic plasticity and adaptations to the urban environmental conditions.

\section{Integrating multiple environmental gradients}

The processes related to urbanization are associated with a multitude of socio-ecological drivers, such as the management intensity of green areas, air, light, and noise pollution, and climatic conditions (temperature, humidity). Because these drivers act simultaneously with different spatio-temporal dynamics, it is increasingly important to study their effects jointly to identify potential non-additive effects on EF and trade-offs on ES.

Urban green space management (e.g. plant and vegetation composition, configuration, structure, and management) affects biodiversity and EF, and can cause trade-offs on ES provision. For example, slow-growing, open-crowned trees such as oaks and maples can increase the aesthetic value and microclimate regulation more than fast-growing narrow-crowned trees (de Abreu-Harbich, Labak \& Matzarakis, 2015), but these effects can be limited during the cold season due to leaf loss, in comparison with evergreen species. Differences among veg- 
etation traits and species composition also affect leaf litter (de)composition, which, in turn, affects environmental conditions for ground-dwelling organisms and their associated ES, such as protection against soil erosion ( $\mathrm{Li}$ et al. 2014), habitat provision for biodiversity (Smith, Broyles, Larzleer \& Fellowes, 2014), organic matter decomposition, and nutrient cycling (Tresch et al., 2019a).

Choices of plant species featuring specific traits by both home gardeners and by managers of public green spaces, has major impacts on biodiversity and multi-trophic interactions. For instance, replacing intensively managed lawns with extensively managed meadows has been shown to enhance pollinator diversity (Baldock, Goddard \& Hicks, 2019) and cultural services (Home et al., 2019), but meadows are less suitable for other recreational activities and may increase a sense of insecurity in people (Fischer, Neuenkamp, Lampinen, ... \& Klaus, 2020; Home et al., 2019). An unintended consequence of plant selection by gardeners and managers of public green spaces is the introduction of exotic and potentially invasive species, and the associated animals (such as herbivore insects) and pathogens (such as fungi and bacteria). While cultivar and exotic species provide ES and may benefit native biodiversity, especially under extensive management and appropriate densities and distributions (Ramírez-Cruz, Solano-Zavaleta, Mendoza-Hernández, Méndez-Janovitz \& Suárez-Rodríguez, 2019), the risk of species becoming invasive must not be minimized, even if these species are particularly appreciated by people, e.g. for their aesthetic value (Marija et al. 2020). Consequences of invasive species may include e.g. being diseases vectors and homogenizing the biotic communities (see (Gaertner et al., 2017)). One important open question is whether exotic and invasive species traits ranges fall within the native species ranges (Finerty et al., 2016) and what are the consequences to Es and EF.

Vegetation can mitigate the effects of urban pollution (e.g. air pollution, (Grote et al., 2016; Matos, Vieira, Rocha, Branquinho \& Pinho, 2019)) but is simultaneously affected by it. For instance, tree morphological, physiological and phenological traits influence the removal of tropospheric ozone (Manes et al., 2012), while volatile-emitting species can contribute to air pollution, providing an ecosystem disservice (Yuan et al., 2020). At the same time, reduced air pollution in European cities (EEA., European Environmental Agency, 2018) has positively influenced sensitive taxa, such as lichens, and nitrogen-tolerant species have recolonized cities after the decline in $\mathrm{SO}_{2}$ (Van Dobben \& Ter Braak, 1998). Nonetheless, water, noise and light pollution are still high in many urban areas (Gaston \& Holt, 2018), impacting biodiversity by adding additional environmental filters (Aronson et al., 2016). However, we have limited knowledge of how changing pollution levels can affect the assembly of urban species (by modifying extinction and colonization rates) and subsequently the ES provided. For example, the shift towards electric vehicles will likely decrease the emissions of NOx in cities. This in turn could potentially reduce acidification and eutrophication, boost the biodiversity of plant communities, and increase the associated ES (Jones et al., 2014).

The urban heat-island effect, i.e. the higher temperature observed in cities than in surrounding rural areas, selects for heat- and drought-tolerant species (Fournier et al., 2020; Piano et al., 2017) and increases primary productivity (Shochat, Warren, Faeth, McIntyre \& Hope, 2006), with possible effects on biotic interactions, leaf litter decomposition (Jochner \& Menzel, 2015; Tresch et al., 2019a) and tree transpiration (Zölch, Maderspacher, Wamsler \& Pauleit, 2016). There are several open questions regarding the effects of climate change superimposed on local urban heat-island effects (Grilo et al., 2020), with birds and plants showing contrasting responses between species (Wohlfahrt, Tomelleri \& Hammerle, 2019).

All the environmental factors listed above act simultaneously on urban biodiversity and associated EF and ES. Their joint effects remain understudied but could be effectively explored by using both an ade- quate sampling design (de Keyzer, Rafferty, Inouye \& Thomson, 2017) and a trait-based approach. The latter may allow us to identify and predict which socio-ecological filtering mechanisms drive species assembly and key ES in urban areas.

\section{Research directions - multiple environmental gradients:}

1. Quantify the multiple environmental drivers of biodiversity and $E F$, and the trade-offs on ES, considering the ecological, cultural, social, and economic dimensions.

2. Assess the new species assemblages, including exotic species, and individual adaptations resulting from changing environmental conditions, including ongoing climate change superimposed on the urban heat-island effect, and its consequences for ES.

Using trait-based approaches to improve our mechanistic understanding of biodiversity relationships with EF and ES

Trait-based approaches make it possible to identify biotic, abiotic and socio-cultural control mechanisms acting on community assemblages and the resulting consequences for EF within and across trophic levels (Diaz et al., 2007), as well as synergies and trade-offs among ES associated with the traits involved (Lavorel \& Grigulis, 2012). Syntheses of empirical studies conducted in non-urban systems have shown that both trait dominance and trait complementarity, although not mutually exclusive (Dias et al., 2013), can be important drivers of EF and ES. As socio-ecological systems, cities challenge our traditional understanding of how species assemblages are filtered and how this, in turn, influences ecosystem functioning, stability and service delivery (Aronson et al., 2016). Which traits and functional components of biodiversity drive EF and ES, and how these can be translated into planning and management guidelines that can be implemented in restoration or conservation activities remains unknown (Luederitz et al., 2015; Schwarz et al., 2017). For example, what type of socio-ecological filters are working during a pandemic situation and that lead people to visit more a given green space than other (Grima et al., 2020) remains unexplored. Investigation of the types of filters, traits and functional components (including those related to socio-economic factors) could therefore unravel the mechanisms linking biodiversity with EF and ES in cities. By understanding these mechanisms predictions of ES under global change and restoration strategies could be improved, e.g. by promoting species assemblages that are able to provide the desired ES (Laughlin, 2014).

Recent studies have highlighted the importance of long-term research (Weisser et al., 2017). While species composition is temporally variable (e.g. due to stochastic processes), functionally redundant species may be abundant in different years, thereby contributing to the overall stability of EF and ES (Isbell et al., 2011; Winfree et al., 2018). Thus, research conducted over long timescales and multi-service provision is an important research direction, due to their paramount importance to understand ecosystem resilience in ES provisioning.

\section{Research directions - trait-based approaches:}

1. Identify relevant socio-environmental filters, species traits and functional components to unravel the mechanisms linking biodiversity and EF with ES. 
2. Identify traits that will become important given future global changes and include them in studies and restoration and conservation guidelines.

\section{Involving citizens in biodiversity, EF and ES research}

Public participation is the involvement of stakeholders (mostly citizens) in public consultations or scientific inquiries and ranges from information exchanges to active decision-making processes (Ambrose-Oji et al., 2017). Citizen scientists can become involved in management and conservation and often improve their urban ecology knowledge in doing so (Deguines, de Flores, Loïs, Julliard \& Fontaine, 2018; Deguines, Princé, Prévot and Fontaine, 2020). Citizen science projects target a broad range of taxa (vertebrates, invertebrates, plants, bacteria, fungi, and protozoa) in many marine and terrestrial ecosystems, many of which are normally inaccessible, such as private gardens. Citizen scientists can also investigate and map the (spatio-temporal dynamics of) urban filters such as air pollution and air temperature (Sauermann et al., 2020). Cities encompass most of the world's human population; consequently, enhancing the collection of data on urban biodiversity in future projects using citizen science will improve the ability of citizens and policy-makers to respond to a wide range of ecological and environmental questions related to e.g. air quality, climate change, invasive species, conservation biology, population ecology, ecosystem functioning, and ecosystem service delivery by increasing the number and size of datasets (Martin, Devictor, Motard, Machon \& Porcher, 2019; Silvertown, 2009). Thus, the involvement of citizens in observing and sampling biodiversity has expanded to the fields of urban governance and planning (Buijs et al., 2016), often driven by global and national policy agendas (e.g. EC 2013, UN-HABITAT 2016).

The usefulness of citizen science projects in science is, however, dependent on the quality of the collected data (Serret et al., 2019) and can be limited by the non-random distribution of sampling effort and poorly classified species (Crall et al., 2011). Future studies in citizen science must ensure that standard protocols developed with statisticians are used (Bird et al., 2014). Another open question regarding citizen science is related to error propagation through complex chains of data collection, because data is collected in very different conditions, by multiple people, and in multiple events. Future research should attempt to identify the main steps of data collection while validating each step along the chain (Snyder, Whitney, Dam, Jacobs and Baumann, 2019).

One way to boost the participation of citizens in future studies is to promote bottom-up initiatives that engage citizens with local green spaces. It is important to ground such initiatives using a combination of social and environmental objectives, rooted in environmental stewardship that goes beyond immediate personal benefit and incorporates wider cultural values (Buijs et al., 2016), thus contributing to science and helping fulfil the aim of monitoring through indicators, as set out in the Sustainable Development Goals (SDG). A powerful tool available to do so is the public participation geographic information system (PPGIS), a method combining spatially explicit data with local knowledge, perceptions and values of individuals or groups of people (Brown \& Fagerholm, 2015). This method should be used in future studies to map ES (Burkhard, Maes, Burkhard \& Maes, 2017), identify cultural and meaningful green spaces (Rall, Bieling, Zytynska \& Haase, 2017), model residents' visits to green spaces (Luz et al., 2019), and identify potential land use conflicts (Brown \& Raymond, 2014) and environmental justice issues (Raymond, Gottwald, Kuoppa \& Kyttä, 2016), amongst many other uses (Rall et al. 2018).

\section{Research directions - involving citizens:}

1. Use standard sampling protocols, include error reporting and analysis, and frame future work within international initiatives, such as the Sustainable Development Goals.

2. Support bottom-up initiatives of citizen science.

\section{Conclusions}

Here, we identified five major research gaps in urban ecology research and put forth suggestions for future research directions, including habitat mapping, neglected habitats and ecological niches, multiple urban gradients, trait-based approaches, and citizens engagement. Overall, trait-based approaches emerged as a common ground to integrate all research directions, from remote sensing detection, measuring impacts of disturbance to targets of citizen science. In fact, trait-based metrics are expected to provide the link of biodiversity with ecosystem functions (EF) and thus ecosystem services (ES). Since these approaches remain poorly investigated in urban environments, especially within the identified research directions, focussing on those directions can help overcome the current knowledge gaps and enable us to make cities more resilient for both nature and human life.

\section{Uncited references}

(Aronson et al., 2014; Diaz \& Cabido, 2001; Jung \& Threlfall, 2018; Kang, Minor, Park \& Lee, 2015; Laanisto et al., 2013; Liu, Kumar, Katul \& Porporato, 2019; Milanović, Knapp, Pyšek \& Kühn, 2020; Pérez-Harguindeguy et al., 2003; Rall, Hansen \& Stephan, 2019; UN 2017).

\section{Declaration of Competing Interest}

The authors declare that they have no known competing financial interests or personal relationships that could have appeared to influence the work reported in this paper.

\section{Acknowledgments}

We acknowledge the questions and suggestions made by the anonymous reviewers of this manuscript that greatly improved the text.

\section{Funding}

This work was partially funded by the European ERA Net BiodivERsA project "BioVEINS: Connectivity of green and blue infrastructures: living veins for biodiverse and healthy cities" (H2020 BiodivERsA32015104). J. Casanelles-Abella was supported by the Swiss National Science Foundation (project 31BD30_172467). M. Alós Ortí was supported by the European Social Fund's Dora Plus Programme, A. C. Luz was funded by the Fundação para a Ciência e Tecnologia (FCT) Portugal (SFRH/BPD/ 108156/2015 fellowship), and A. Kubicka acknowledges Poland funding through NCN/2016/22/Z/NZ8/00004.

\section{References}

B., Ambrose-Oji, A., Buijs, E., Geróházi, T., Mattijssen, L., Száraz, \& A., Van der Jagt, et al. (2017). Innovative governance for urban green infrastructure, a guide for practitioners. Copenhagen, Denmark: University of Copenhagen. GREEN SURGE project Deliverable 6.3.

M.F.J., Aronson, C.H., Nilon, C.A., Lepczyk, T.S., Parker, P.S., Warren, \& S.S., Cilliers, et al. (2016). Hierarchical filters determine community assembly of urban species pools. Ecology, 97, 2952-s063.

M.F.J., Aronson, F.A.L., Sorte, C.H., Nilon, M., Katti, \& M.A., Goddard, et al. (2014). A global analysis of the impacts of urbanization on bird and plant diversity reveals key 
anthropogenic drivers. Proceedings of the Royal Society B, Biological Sciences, 281, 20133330.

K.C.R., Baldock, M.A., Goddard, \& D.M., Hicks, et al. (2019). A systems approach reveals urban pollinator hotspots and conservation opportunities. Nature Ecology \& Evolution, 3 , 363-373.

T.J., Bird, A.E., Bates, J.S., Lefcheck, N.A., Hill, R.J., Thomson, \& G.J., Edgar, et al. (2014). Statistical solutions for error and bias in global citizen science datasets. Biological Conservation, 173, 144-154.

N.L., Boivin, M.A., Zeder, D.Q., Fuller, A., Crowther, G., Larson, \& J.M., Erlandson, et al. (2016). Ecological consequences of human niche construction, examining long-term anthropogenic shaping of global species distributions. Proceedings of the National Academy of Sciences of the United States of America, 113, 6388-6396.

G., Brown, \& N., Fagerholm (2015). Empirical PPGIS/PGIS mapping of ecosystem services, a review and evaluation. (2015). Ecosystem Services, 13, 119-133.

G., Brown, \& C.M., Raymond (2014). Methods for identifying land use conflict potential using participatory mapping. Landscape and Urban Planning, 122, 196-208. A.E., Buijs, T.J.M., Mattijssen, A.P.N., Van der Jagt, B., Ambrose-Oji, E., Andersson, \& B.H.M., Elands, et al. (2016). Active citizenship for urban green infrastructure, fostering the diversity and dynamics of citizen contributions through mosaic governance. Current Opinion in Environmental Sustainability, 22, 1-6.

B., Burkhard, \& J, Maes (Eds.). (2017). Mapping ecosystem services (p. 374). Sofia: Pensoft Publishers.

G., Capotorti, M.M., Alós Ortí, R., Copiz, L., Fusaro, B., Mollo, \& E., Salvatori, et al. (2019). Biodiversity and ecosystem services in urban green infrastructure planning, a case study from the metropolitan area of Rome (Italy). Urban Forestry \& Urban Greening, 37, 87-96.

J., Colding (2007). "Ecological land-use complementation" for building resilience in urban ecosystems. Landscape and Urban Planning, 81, 46-55.

A.W., Crall, G.J., Newman, T.J., Stohlgren, K.A., Holfelder, J., Graham, \& D.M., Waller (2011). Assessing citizen science data quality, an invasive species case study. Conservation Letters, 4, 433-442.

S.K., Dawson, L., Boddy, \& H., Halbwachs, et al. (2019). Handbook for the measurement of macrofungal functional traits, a start with basidiomycete wood fungi. Fuctional Ecology, 33, 372-387.

V., de Abreu-Harbich, L., Labak, \& A., Matzarakis (2015). Effect of tree planting design and tree species on human thermal comfort in the tropics. Landscape and Urban Planning, 138, 99-109.

C.W., de Keyzer, N.E., Rafferty, D.W., Inouye, \& J.D., Thomson (2017). Confounding effects of spatial variation on shifts in phenology. Global Change Biology, 23, 1783-1791. N., Deguines, M., de Flores, G., Loïs, R., Julliard, \& C., Fontaine (2018). Fostering close encounters of the entomological kind. Frontiers in Ecology and the Environment, 16, 202-203.

N., Deguines, K., Princé, A.-.C., Prévot, \& B., Fontaine (2020). Assessing the emergence of pro-biodiversity practices in citizen scientists of a backyard butterfly survey. Science of The Total Environment, 136842

A.T.C., Dias, M.P., Berg, .F., de Bello, A.R., Van Oosten, .K., Bila, \& .M., Moretti (2013) An experimental framework to identify community functional components driving ecosystem processes and services delivery. Journal of Ecology, 101, 29-37. S., Diaz, \& M., Cabido (2001). Vive la difference, plant functional diversity matters to ecosystem processes. Trends in Ecology \& Evolution, 16, 646-655.

S., Diaz, S., Lavorel, F., de Bello, F., Quétier, K., Grigulis, \& T., Robson (2007).

Incorporating plant functional diversity effects in ecosystem service assessments. Proceedings of the National Academy of Sciences, 104, 20684-20689.

S., Diaz, U., Pascual, M., Stenseke, B., Martín-López, R.T., Watson, \& Z., Molnár, et al. (2018). Assessing nature's contributions to people. Science, 359, 270-272.

C., Dobbs, A., Hernandez-Moreno, S., Reyes-Paecke, \& M.D., Miranda (2018). Exploring temporal dynamics of urban ecosystem services in Latin America, The case of Bogota (Colombia) and Santiago (Chile). Ecological Indicators, 85, 1068-1080.

EC. (2020). NATURA 2000 in cities. Luxembourg: Publications Office of the European Union. 2020 https://ec.europa.eu/environment/nature/natura2000.

EEA., European Environmental Agency (2012). European urban atlas. EC., Copenhagen, Denmark.

EEA., European Environmental Agency (2018). Air quality in Europe - 2018 report. EC., Copenhagen, Denmark.

T., Elmqvist, E., Andersson, \& N., Frantzeskaki, et al. (2019). Sustainability and resilience for transformation in the urban century. Nature Sustainability, 2, 267-273. K., Engemann, C.B., Pedersen, L., Arge, C., Tsirogiannis, P.B., Mortensen, \& J.C., Svenning (2019). Residential green space in childhood is associated with lower risk of psychiatric disorders from adolescence into adulthood. Proceedings of the National Academy of Sciences of the United States of America, 116, 5188-5193.

G.E., Finerty, F., de Bello, K., Bílá, M.P., Berg, A.T., Dias, \& G.B., Pezzatti, et al. (2016). Exotic or not, leaf trait dissimilarity modulates the effect of dominant species on mixed litter decomposition. Journal of Ecology, 104, 1400-1409.

L.K., Fischer, L., Neuenkamp, J., Lampinen, \& V.H., Klaus (2020). Public attitudes toward biodiversity-friendly greenspace management in Europe. Conservation Letters, 13(13), E12718.

B., Fournier, D., Frey, \& M., Moretti (2020). The origin of urban communities, from the regional species pool to community assemblages in city. Journal of biogeography, 47 $615-629$.

M., Gaertner, J.R.U., Wilson, M.W., Cadotte, J.S., MacIvor, R.D., Zenni, \& D.M., Richardson (2017). Non-native species in urban environments: Patterns, processes, impacts and challenges. Biological Invasions, 19, 3461-3469.

K.J., Gaston, \& L.A., Holt (2018). Nature, extent and ecological implications of night-time light from road vehicles. Journal of Applied Ecology, 55, 2296-2307.
F., Grilo, P., Pinh.o, C., Aleixo, C., Catita, P., Silva, \& N., Lopes, et al. (2020). Using green to cool the grey: Modelling the cooling effect of green spaces with a high spatial resolution. Science of the Total Environment, 724, 138182

N., Grima, W., Corcoran, C., Hill-James, B., Langton, H., Sommer, \& B., Fisher (2020) The importance of urban natural areas and urban ecosystem services during the COVID-19 pandemic. PloS one, 15, E0243344.

R., Grote, R., Samson, R., Alonso, J.H., Amorim, P., Cariñanos, \& G., Churkina, et al. (2016). Functional traits of urban trees: Air pollution mitigation potential. Frontiers in Ecology and Environment, 14, 543-550.

K.L., Hand, C., Freeman, P.J., Seddon, M.R., Recio, A., Stein, \& Y., van Heezik (2017). The importance of urban gardens in supporting children's biophilia. Proceedings of the National Academy of Sciences of the United States of America, 114, 274-279.

R., Home, O., Lewis, N., Bauer, A., Fliessbach, D., Frey, \& S., Lichtsteiner, et al. (2019). Effects of garden management practices, by different types of gardeners, on human wellbeing and ecological and soil sustainability in Swiss cities. Urban Ecosystems, 22, 189-199.

IPBES. (2019). The global assessment report on summary on policymakers of the IPBES

global assessment report on biodiversity and ecosystem services. Retrieved from https:

//ipbes.net/system/tdf/ipbes_global_assessment_report_summary_for_policymakers. pdf? file $=1 \&$ type $=$ node\&id $=35329$

F., Isbell, V., Calcagno, A., Hector, J., Connolly, W.S., Harpole, \& P.B., Reich, et al. (2011). High plant diversity is needed to maintain ecosystem services. Nature, 477, 199-202.

S., Jochner, \& A., Menzel (2015). Urban phenological studies-past, present, future. Environmental Pollution, 203, 250-261.

L., Jones, .A., Provins, .M., Holland, .G., Mills, .F., Hayes, \& .B., Emmett, et al. (2014). A review and application of the evidence for nitrogen impacts on ecosystem services. Ecosystem Services, 7, 76-88.

K., Jung, \& C.G., Threlfall (2018). Trait-dependent tolerance of bats to urbanization, a global meta-analysis. Proceedings of the Royal Society B, Biological Sciences, 285,

\section{2. doi:10.1098/rspb.2018.1222 CR}

N., Kabisch, M., Strohbach, D., Haase, \& J., Kronenberg (2016). Urban green space availability in European cities. Ecological Indicators, 70, 586-596.

W., Kang, E.S., Minor, C.R., Park, \& D., Lee (2015). Effects of habitat structure, human disturbance, and habitat connectivity on urban forest bird communities. Urban Ecosystems, 18, 857-870.

E., Knop, L., Zoller, R., Ryser, C.G., Erpe, M., Horler, \& C., Fontaine (2017). Artificial light at night as a new threat to pollination. Nature, 548, 7666. doi:10.1038/nature23288

\section{C'R}

L., Laanisto, R., Tamme, I., Hiiesalu, R., Szava-Kovats, A., Gazol, \& M., Pärtel (2013). Microfragmentation concept explains non-positive environmental heterogeneity-diversity relationships. Oecologia, 171, 217-226.

D.C., Laughlin (2014). Applying trait-based models to achieve functional targets for theory-driven ecological restoration. Ecology Letters, 17, 771-784.

S., Lavorel, \& K., Grigulis (2012). How fundamental plant functional trait relationships scale-up to trade-offs and synergies in ecosystem services. Journal of Ecology, 100, 128-140.

Y., Liu, M., Kumar, G.G., Katul, \& A., Porporato (2019). Reduced resilience as an early warning signal of forest mortality. Nature Climate Change, 9, 880-885.

C., Luederitz, E., Brink, F., Gralla, V., Hermelingmeier, M., Meyer, \& L., Niven, et al. (2015). A review of urban ecosystem services, six key challenges for future research. Ecosystem Services, 14, 98-112.

A.C., Luz, M., Buijs, C., Aleixo, I., Metelo, F., Grilo, \& C., Branquinho, et al. (2019). Should I stay or should I go? Modelling the fluxes of urban residents to visit green spaces. Urban Forestry and Urban Greening, 40, 195-203.

F., Manes, G., Incerti, E., Salvatori, M., Vitale, C., Ricotta, \& R., Costanza (2012). Urban ecosystem services, tree diversity and stability of tropospheric ozone removal. Ecological Applications, 22, 349-360.

G., Martin, V., Devictor, E., Motard, N., Machon, \& E., Porcher (2019). Short-term climate-induced change in French plant communities. Biology Letters, 15, 20190280. P., Matos, J., Vieira, B., Rocha, C., Branquinho, \& P., Pinho (2019). Modeling the provision of air-quality regulation ecosystem service provided by urban green spaces using lichens as ecological indicators. Science of the Total Environment, 654, 705-713. T., Mexia, J., Vieira, A., Principe, A., Anjos, P., Silva, \& N., Lopes, et al. (2018). Ecosystem services, Urban parks under a magnifying glass. Environmental Research, 160, 469-478.

C., Meyer, P., Weigelt, \& H., Kreft (2016). Multidimensional biases, gaps and uncertainties in global plant occurrence information. Ecology Letters, 19, 992-1006. M., Milanović, S., Knapp, P., Pyšek, \& I., Kühn (2020). Linking traits of invasive plants with ecosystem services and disservices. Ecosystem Services, 42, 101072

M., Moretti, A., Dias, \& F., De Bello, et al. (2017). Handbook of protocols for standardized measurements of terrestrial invertebrate functional traits. Functional Ecology, 31, 558-567.

S., Munzi, O., Correia, P., Silva, N., Lopes, C., Freitas, \& C., Branquinho, et al. (2014). Lichens as ecological indicators in urban areas, beyond the effects of pollutants. Journal of Applied Ecology, 51, 1750-1757.

A., Ossola, D., Locke, B., Lin, \& E., Minor (2019). Greening in style, urban form, architecture and the structure of front and backyard vegetation. Landscape and Urban Planning, 185, 141-157.

V., Pellissier, A., Mimet, C., Fontaine, J.C., Svenning, \& D., Couvet (2017). Relative importance of the land-use composition and intensity for the bird community composition in anthropogenic landscapes. Ecology and Evolution, 7, 10513-10535. 
N., Pérez-Harguindeguy, S., Díaz, F., Vendramini, J.H.C., Cornelissen, D.E., Gurvich, \& M., Cabido (2003). Leaf traits and herbivore selection in the field and in cafeteria experiments. Austral Ecology, 28, 642-650.

E., Piano, K., De Wolf, F., Bona, D., Bonte, D.E., Bowler, \& M., Isaia, et al. (2017)

Urbanization drives community shifts towards thermophilic and dispersive species at

local and landscape scales. Global Change Biology, 23, 2554-2564.

P., Pinho, S., Augusto, M.A., Martins-Loucao, M.J., Pereira, A., Soares, \& C., Maguas, et

al. (2008). Causes of change in nitrophytic and oligotrophic lichen species in a

Mediterranean climate, Impact of land cover and atmospheric pollutants. Environmental

Pollution, 154, 380-389.

P., Pinho, O., Correia, M., Lecoq, S., Munzi, S., Vasconcelos, \& P., Goncalves, et al.

(2016). Evaluating green infrastructure in urban environments using a multi-taxa and

functional diversity approach. Environmental Research, 147, 601-610.

E., Rall, C., Bieling, S., Zytynska, \& D., Haase (2017). Exploring city-wide patterns of

cultural ecosystem service perceptions and use. Ecological Indicators, 77, 80-95.

E., Rall, R., Hansen, \& P., Stephan (2019). The added value of public participation GIS

(PPGIS) for urban green infrastructure planning. Urban Forestry \& Urban Greening, 40, 264-274.

C.E., Ramalho, \& R.J., Hobbs (2012). Time for a change, dynamic urban ecology. Trends in Ecology \& Evolution, 27, 179-188.

G.A., Ramírez-Cruz, I., Solano-Zavaleta, P.E., Mendoza-Hernández, M., Méndez-Janovitz, \& M., Suárez-Rodríguez, et al. (2019). This town ain't big enough for both of us...or is it? Spatial co-occurrence between exotic and native species in an urban reserve. PloS one, 14, e0211050.

C.M., Raymond, S., Gottwald, J., Kuoppa, \& M., Kyttä (2016). Integrating multiple elements of environmental justice into urban blue space planning using public participation geographic information systems. Landscape and Urban Planning, 153, 198-208.

H., Sauermann, K., Vohland, V., Antoniou, B., Balázs, C., Göbel, \& K., Karatzas, et al (2020). Citizen science and sustainability transitions. Research Policy, 49, 103978. N., Schwarz, M., Moretti, M.N., Bugalho, Z.G., Davies, D., Haase, \& J., Hack, et al. (2017). Understanding biodiversity-ecosystem service relationships in urban areas, a comprehensive literature review. Ecosystem Services, 27, 161-171.

H., Serret, N., Deguines, Y., Jang, G., Lois, \& R., Julliard (2019). Data quality and participant engagement in citizen science, comparing two approaches for monitoring pollinators in France and South Korea. Citizen Science, Theory and Practice, 4, 22.

E., Shochat, P.S., Warren, S.H., Faeth, N.E., McIntyre, \& D., Hope (2006). From patterns to emerging processes in mechanistic urban ecology. Trends in Ecology \& Evolution, 21, 186-191.

J., Silvertown (2009). A new dawn for citizen science. Trends in Ecology and Evolution, 24, 467-471.

L.S., Smith, M.E.J., Broyles, H.K., Larzleer, \& M.D.E., Fellowes (2014). Adding ecological value to the urban lawnscape. Insect abundance and diversity in grass-free lawns. Biodiversity and Conservation, 24, 47-62.

J.T., Snyder, M.M., Whitney, H.G., Dam, M.W., Jacobs, \& H., Baumann (2019). Citizen science observations reveal rapid, multi-decadal ecosystem changes in eastern Long Island Sound. Marine Environmental Research, 146, 80-88.

S., Tresch, D., Frey, R.C., Le Bayon, P., Mader, B., Stehle, \& A., Fliessbach, et al. (2019b). Direct and indirect effects of urban gardening on aboveground and belowground diversity influencing soil multifunctionality. Scientific Reports, 9, 9769.

S., Tresch, D., Frey, R.C., Le Bayon, A., Zanetta, F., Rasche, \& A., Fliessbach, et al. (2019a). Litter decomposition driven by soil fauna, plant diversity and soil management in urban gardens. Science of the Total Environment, 658, 1614-1629.

K., Uchida, R.V., Blakey, J.R., Burger, D.S., Cooper, C.A., Niesner, \& D.T., Blumstein

(2021). Urban biodiversity and the importance of scale. Trends in Ecology \& Evolution, $36,123-131$.

UN, (2017). New Urban Agenda - Habitat III. Page 30 in General Assembly of the United Nations. UN-HABITAT (2016). Goal 11, Make cities inclusive, safe, resilient and sustainable.

H.F., Van Dobben, \& C.J.F., Ter Braak (1998). Effects of atmospheric NH3 on epiphytic lichens in the Netherlands, the pitfalls of biological monitoring. Atmospheric Environment, 32, 551-557.

L., Villarroya-Villalba, J., Casanelles-Abella, M., Moretti, P., Pinho, A., van Mensel, \& F., Chiron, et al. (2021). Response of bats and nocturnal insects to urban green areas in Central Europe. Basic and Applied Ecology. in press.

W.W., Weisser, C., Roscher, S.T., Meyer, A., Ebeling, G., Luo, \& E., Allan, et al. (2017). Biodiversity effects on ecosystem functioning in a 15-year grassland experiment, Patterns, mechanisms, and open questions. Basic and Applied Ecology, 23, 1-73.

R., Winfree, J.R., Reilly, I., Bartomeus, D.P., Cariveau, N.M., Williams, \& J., Gibbs (2018). Species turnover promotes the importance of bee diversity for crop pollination at regional scales. Science, 359, 791-793.

G., Wohlfahrt, E., Tomelleri, \& A., Hammerle (2019). The urban imprint on plant phenology. Nature Ecology \& Evolution, 3, 1668-1674.

Y., Yuan, Z., Sun, A., Kännaste, M., Guo, G., Zhou, \& U., Niinemets (2020). Isoprenoid and aromatic compound emissions in relation to leaf structure, plant growth form and species ecology in 45 East-Asian urban subtropical woody species. Urban Forestry \& Urban Greening, 53, 126705.

T., Zölch, J., Maderspacher, C., Wamsler, \& S., Pauleit (2016). Using green infrastructure for urban climate-proofing: An evaluation of heat mitigation measures at the micro-scale. Urban Forestry \& Urban Greening, 20, 305-316. 